Krzysztof Wáz

Uniwersytet Zielonogórski

\title{
Nastoletni chłopcy w roli ojca. Dwie odsłony socjalizacyjne
}

Wśród przemian społeczno-kulturowych wzorów płci odnoszących się do męskości być może najbardziej radykalne są te, które łączą się z pełnieniem roli ojca. W stosunku do "nowego ojca” adresowane są współcześnie oczekiwania społeczne znacząco odmienne od tych, które były kierowane do mężczyzn posiadających dzieci przez ostatnie stulecia, oczekiwania, sprostanie którym wymaga przezwyciężenia nie tylko stereotypu ojca, ale też stereotypu „męskiego mężczyzny". Sytuacja taka wymaga znaczących modyfikacji procesu socjalizacji do ról płciowych realizowanego $\mathrm{w}$ odniesieniu do nastoletnich chłopców. Bez takich zmian młodzi mężczyźni mogą stać się bezradni wobec zadań wynikających z na nowo zdefiniowanej roli ojca, zwłaszcza wtedy, gdy do pełnienia takiej roli będą zmuszeni przystąpić jako nastoletni chłopcy.

W niniejszym artykule zostanie podjęta próba zaprezentowania dwóch bardzo specyficznych rodzajów doświadczeń socjalizacyjnych nastoletnich chłopców związanych z rolą ojca. Pierwszy z nich dotyczy sytuacji realnej, w której nastolatek ma zostać ojcem. W drugiej chłopak odgrywa jedynie rolę ojca w wyniku udziału w programie edukacyjnym. Do prezentacji tych doświadczeń posłużą dane z dwóch badań, których wyniki zostały na potrzeby tego opracowania poddane reinterpretacji.

\section{Socjalizacja do roli ojca}

Współcześnie, szczególnie w ostatnim trzydziestoleciu, obserwujemy proces odejścia do lamusa wzoru "ojca-króla”, „ojca-Boga”, a nawet „ojca nieobecnego" (Sikorska 2009, s. 192) i pojawienia się, coraz wyraźniej zdefiniowanego, wzoru nowego ojca - mężczyzny zaangażowanego w opiekę i wychowanie swojego potomka od pierwszych chwil życia, asystującego przy porodzie, podejmującego czynności niegdyś wyraźnie zarezerwowane dla matki, ojca, który na zasadzie 
rzeczywistego partnerstwa podejmuje czynności rodzicielskie na równi z matką, a czasami wręcz ją w nich wyręcza, choćby w trakcie urlopu tacierzyńskiego.

W tej sytuacji socjalizacja i wychowanie do ojcostwa jawią się jako niezwykle złożone zadania. Jak, przekazując nastoletniemu chłopcu wzór zaangażowanego ojca, także zaangażowanego emocjonalnie, wrażliwego na potrzeby małego dziecka, nie doprowadzić do zbyt daleko idącej „feminizacji” socjalizacji do męskości, do sytuacji „tożsamościowej nieadekwatności” wobec oczekiwań otoczenia społecznego? Sytuacji nie ułatwia „panika moralna” sprowokowana przez osoby prowadzące krucjatę ideologiczną pod hasłem „walki z ideologią gender”, które wszelkie odstępstwa od tradycyjnego modelu w socjalizacji rodzajowej traktują jako chęć zburzenia „naturalnego”, konserwatywnego porządku społecznego i demoralizację.

Funkcjonujące obecnie wzory ról płciowych nie zastępują tych wcześniejszych, ale pojawiają się obok, tworząc swoiste napięcia między tradycyjnymi i nowymi rolami (Kwiatkowska 1999). Przy czym nie odbywa się to bez znaczących kosztów, gdyż np. do mężczyzny pełniącego rolę ojca kieruje się wiele nowych wymagań, nie eliminując tych, które wynikają ze starego modelu. „Współczesne przekazy socjalizacyjne zdają się odzwierciedlać swoistą ambiwalencję między silnie zakorzenionymi wzorami tradycyjnymi a egalitarnymi, wynikającymi z wymagań współczesności" (Paprzycka 2010, s. 34). Ambiwalencja ta w przypadku chłopców przejawia się z jednej strony w kształtowaniu cech uważanych za typowo męskie, z drugiej zaś cech tradycyjnie przypisanych kobiecie, czyli między innymi takich, które umożliwiają sprawną opiekę nad dzieckiem.

Do głównych agend socjalizacyjnych, wpływających na przyswajanie przez jednostkę stereotypów związanych z płcią, należy zaliczyć: rodzinę, szkołę, Kościół, grupę rówieśniczą oraz środki masowego przekazu. Ze względu na problematykę niniejszego opracowania w tym miejscu można tylko krótko wspomnieć o roli pierwszych dwóch z tych agend.

Socjalizacja chłopców do roli ojca rozpoczyna się w rodzinie. Socjalizacja pierwotna $\mathrm{w}$ tym zakresie odbywa się poprzez relacje z własnym ojcem. Dzisiaj trudno jednak chłopcu liczyć na wsparcie „we wzorach płynących od ojców ze starszych generacji, którzy dostawali dzieci w swoje ręce dopiero wtedy, kiedy uczyli je przestrzegania norm społecznych (czyli późno)” (Szlendak 2011, s. 448). Ponadto dawniej, w rodzinach wielodzietnych, chłopcy nierzadko obserwowali relacje ojca z młodszym rodzeństwem, obserwowali pełnienie przez niego tej roli, mogli także, a czasami musieli, opiekować się młodszym rodzeństwem. Współcześnie znacząca część chłopców jest w ogóle pozbawiona takich doświadczeń, a nawet pozbawiona codziennych kontaktów z własnym ojcem.

Szkoła oddziałuje na proces typizacji płciowej przede wszystkim przez podręczniki oraz przekazy nauczycielskie (Muszyńska 2004). Na ironię zasługuje to, że najbardziej tradycyjny przekaz, nieuwzględniający zmian zachodzących w przepisach ról płciowych, w tym we wzorcu roli ojca, występuje na zajęciach wychowania do życia w rodzinie (Izdebski, Wąż 2010). W podręcznikach szkolnych członkowie rodzin i ich wzajemne relacje prezentowane są na ogół w sposób tra- 
dycyjny i stereotypowy. „Mężczyźni rzadko przedstawiani są w rolach rodzinnych. A już ojca sprawującego opiekę nad niemowlęciem albo chorym dzieckiem nie zobaczymy na pewno. Podręcznikowy tata, to tata świąteczny, niedzielny" (Wołosik 2011). W nowszych podręcznikach można jednak dostrzec próby przełamywania stereotypów płciowych, ukazywania kobiet poza sferą prywatną, a mężczyzn zaangażowanych w życie rodzinne, w tym w opiekę nad małym dzieckiem. Także nauczyciele i nauczycielki nie są wolni od stereotypów płciowych, w związku z czym (najczęściej nieświadomie, w ramach tzw. ukrytego programu szkoły) w odmienny sposób traktują uczniów i uczennice. To właśnie ukryty program szkoły (poprzez socjalizacyjne przekazy nauczycieli oraz treści podręczników szkolnych) reprodukuje stereotypy płciowe, także stereotypy dotyczące ojcostwa.

\section{Pierwsza odsłona socjalizacyjna - nastoletni ojcowie}

Młodzież prezentuje zróżnicowane postawy wobec aktywności seksualnej, ale jest to stosunek coraz bardziej liberalny. Widać to bardzo wyraźnie w badaniach szesnastolatków. Niemal jedna czwarta z nich $(24 \%)$ była zdania, że współżycie płciowe w ich wieku jest czymś normalnym. Ponad połowa (53\%) respondentów podzielała pogląd, że osoby w ich wieku mogą podejmować pewne formy aktywności seksualnej, ale z całkowitym wyłączeniem stosunków płciowych. Tylko 13\% respondentów opowiedziało się za najbardziej restryktywnym stanowiskiem, twierdząc, że osoby w ich wieku zdecydowanie nie powinny jeszcze podejmować żadnej formy aktywności seksualnej (nawet pieszczot). Warto podkreślić, że chłopcy prezentowali poglądy bardziej przyzwalające, tj. nieco rzadziej, w porównaniu z dziewczętami, opowiadali się za normą „osoby w moim wieku zdecydowanie nie powinny jeszcze podejmować aktywności seksualnej", oraz znacznie częściej wyrażali aprobatę dla normy „współżycie płciowe osób w moim wieku jest czymś normalnym”. Większość szesnastolatków (54\%) uważała, że rozpoczęcie życia seksualnego może nastąpić przed ukończeniem 20 roku życia, przy czym niemal jedna czwarta (24\%) sytuowała ten moment jeszcze wcześniej, przed osiągnięciem dorosłości. Chłopcy niemal dwa razy częściej niż dziewczęta uznawali, iż aktywność seksualną mogą podejmować osoby, które nie ukończyły jeszcze 18 roku życia (Wąż 2008). Wyniki badań zrealizowanych w 2010 roku pozwalają stwierdzić, że w przypadku 15-16-latków 20,0\% chłopców i 13,7\% dziewcząt miało za sobą inicjację seksualną. W przypadku 17-18-latków było to już 45,3\% chłopców oraz 38,5\% dziewcząt (Mazur, Małkowska-Szkutnik 2010). Warto jednak dostrzec, że zjawisko obniżania wieku inicjacji seksualnej dotyczy w większej mierze dziewcząt. W okresie minionych 20 lat (1990-2010) odsetek młodzieży po inicjacji seksualnej w przypadku chłopców zwiększył się tylko o kilka (2-9) punktów procentowych (większy wzrost w starszej grupie), natomiast u dziewcząt zwiększył się aż dwu- lub trzykrotnie (większy wzrost w grupie 
wiekowej 15-16 lat) (Woynarowska, Szymańska, Mazur 1999; Mazur, Małkowska-Szkutnik 2010).

Zbyt wczesne i nieodpowiedzialne podejmowanie współżycia seksualnego, brak wiedzy z zakresu antykoncepcji łączy się - w niektórych przypadkach z przedwczesną prokreacją i rodzicielstwem. Ojcostwo nastoletnich chłopców nigdy nie wzbudzało dużego zainteresowania społecznego, ani nie było traktowane jako ważny problem refleksji naukowej. To macierzyństwo dziewcząt wzbudza duże zainteresowanie i niemałe emocje, a pełnienie roli ojca przez równie młodego chłopca uznawane jest co najwyżej za dodatkowe utrudnienie sytuacji młodej matki i (w przypadku bardzo młodego wieku obojga rodziców) koronny dowód na ich nieodpowiedzialność.

Ciąża i narodziny dziecka $w$ przypadku kobiety należą do znaczących wydarzeń w toku życia, wydarzeń, które mogą być zarówno stymulatorem rozwoju, jak i doświadczeniem kryzysowym, czy wręcz zdarzeniem krytycznym (Skowrońska-Zbierzchowska 2010). Tezę tę można odnieść także do wielu mężczyzn, zwłaszcza nastoletnich chłopców. „Rozszczepienie dojrzewania”, czyli brak zgodności pomiędzy tempem rozwoju biologicznego, seksualnego, psychicznego i społecznego, jaką obserwujemy u osób w okresie dorastania (Jaczewski 1992), uniemożliwia podjęcie w sposób dojrzały i odpowiedzialny roli ojca. Wczesne rodzicielstwo stawia przed nastoletnimi chłopcami zadania na miarę możliwości człowieka dorosłego, natomiast blokuje szanse na rozwiązywanie zadań rozwojowych, typowych dla okresu dorastania. Nie są przygotowani do podjęcia obowiązków ojca pod względem psychicznym, emocjonalnym, społecznym, także ekonomicznym. Brak pełnoletności jest też zasadniczą przeszkodą prawną w sprawowaniu formalnej opieki nad dzieckiem.

Statystyki wczesnej prokreacji w odniesieniu do chłopców są dalece niekompletne, bo tylko od rodzących kobiet zależy, czy zechcą ujawnić dane ojca dziecka. Wśród mężczyzn uznanych za ojców przez kobiety, które urodziły żywe dziecko w 2004 roku, było 3054 osób poniżej 19 roku życia $(0,86 \%)$, przy czym 17348 matek $(4,87 \%)$ nie podało danych ojca. W 2013 roku było takich osób 1996 (0,54\%) a 14002 matki $(3,77 \%)$ nie podały danych ojca. Sytuację jeszcze bardziej komplikuje to, że wśród kobiet, które ujawniły, że ojcem ich dziecka jest nastoletni chłopak, dominowały ich rówieśniczki. Wśród kobiet, które nie ujawniły danych ojca, także dominowały nastoletnie dziewczęta. Należy dodać, że mitem jest powszechność sytuacji, w których oboje rodzice to osoby niepełnoletnie. Nastoletnie matki najczęściej wskazywały, że ojcem ich dziecka jest młody, ale już pełnoletni, mężczyzna (Dane demograficzne GUS 2014).

Jakie doświadczenia socjalizacyjne są udziałem nastoletnich chłopców, którzy zostali ojcami? Jakie czynniki i na ile różnicują te doświadczenia? Próba odpowiedzi na te pytania zostanie podjęta poniżej $w$ oparciu o reinterpretację materiału badawczego uzyskanego w badaniach jakościowych przeprowadzonych w 2008 i 2009 roku na próbach 30 kobiet i 30 mężczyzn, którzy zostali rodzicami przed ukończeniem 18 roku życia. Wyniki tych badań zostały zaprezentowane w monografii poświęconej problemowi rodzicielstwa nastolatków (Izdebski, Wąż 2011). 
Analiza wypowiedzi mężczyzn, którzy zostali ojcami jako nastolatkowie, oraz wypowiedzi kobiet, które w tym samym wieku zostały matkami i prezentowały reakcje i postępowanie niepełnoletnich ojców ich dzieci, pozwalają na wyłonienie szeregu czynników, które miały wpływ na obraz ich doświadczeń socjalizacyjnych związanych z tą sytuacją.

Pierwszym z tych czynników jest świadomość ciąży partnerki (urodzenia przez nią dziecka). Jest to warunek sine qua non. Bez świadomości tego faktu chłopak nie mógł - z oczywistych względów - podjąć się pełnienia tej roli. Tymczasem w niektórych przypadkach dziewczęta (często pod wpływem presji rodziców) nie informowały o ciąży chłopca, bądź informowały bardzo późno. Czasami chłopak dowiadywał się wręcz od innych, postronnych osób o ciąży dziewczyny. Nie bez znaczenia było także to, w jakim momencie dowiadywał się o tym, że ma zostać/został ojcem. Badani, którzy dowiadywali się o tym na początku ciąży, mieli więcej czasu na poradzenie sobie z problemem, niektórzy także na wcześniejsze wejście w rolę, na przeżywanie, przygotowywanie się wraz $\mathrm{z}$ partnerką do porodu, na wspieranie jej w tym trudnym, także z racji wieku, okresie.

Kolejnym uwarunkowaniem jest rodzaj relacji chłopca z matką dziecka. W większości były to aktualne partnerki - „dziewczyny” badanych. Jednak związki młodzieńcze często bywają krótkie i burzliwe. Bywało też tak, że przed uświadomieniem sobie przez dziewczynę, że jest w ciąży jej związek z ojcem dziecka był już zakończony, czasami byli też bardzo skłóceni. Relatywnie często ciąża dziewczyny była także efektem przelotnego związku, bądź wręcz incydentalnej znajomości zawartej często w toku imprezy, pod wpływem alkoholu. Młodzi więc praktycznie nie znali się.

O rodzaju i zakresie doświadczeń socjalizacyjnych związanych z wczesnym rodzicielstwem w dużym stopniu decyduje to, na ile chłopak zaakceptuje siebie w tej roli. Czy nie będzie stosował strategii ucieczki, wyparcia się ojcostwa. Na ile zracjonalizuje, opanuje szok, przerażenie, które w zdecydowanej większości badanych przypadków były skutkiem informacji o ciąży dziewczyny. Wreszcie, na ile zaangażuje się we wsparcie matki dziecka w okresie ciąży i w opiekę nad dzieckiem po jego przyjściu na świat. Na ile będzie chciał i mógł na co dzień partycypować w tej opiece.

Czynnikiem, który znacząco wpływa na możliwości podjęcia przez nastolatka roli ojca, jest także sposób, w jaki traktują go dziewczyna i jej rodzice. Nawet wtedy, gdy młodego ojca łączyła z dziewczyną bliska więź i mieli za sobą doświadczenia relatywnie długiego młodzieńczego związku, nie może on liczyć na zaakceptowanie go w nowej roli. Jako „kandydat” na ojca przechodzi ponowny proces weryfikacji, zwłaszcza przez rodziców dziewczyny. Ocena ta często jest niepomyślna. Nowa rola wymaga innych przymiotów niż te, które były cenione u chłopaka, z którym dobrze spędza się czas i bawi. Jeszcze gorzej wypada ocena chłopaka, który wcześniej w ogóle nie był znany rodzicom dziewczyny, a czasem i jej samej. 
W przypadku nastoletnich chłopców decydujący wpływ na to, czy w ogóle i na ile będą mogli podjąć się pełnienia roli ojca własnego dziecka ma stosunek dorosłych (zwłaszcza jego rodziców i rodziców matki dziecka) do zaistniałej sytuacji. To oni decydują w praktyce o wszystkim bądź prawie wszystkim. W pierwszym rzędzie o tym, czy dziecko w ogóle przyjdzie na świat. Aborcja w przypadku zajścia w ciążę młodej dziewczyny jest rozważana stosunkowo często. Choć w badaniach jakościowych uczestniczyły tylko osoby, których dziecko przyszło na świat, to w tej grupie także w co najmniej kilku przypadkach brano pod uwage aborcję. Rodzice nastolatków (a zwłaszcza rodzice dziewczyny) decydują o tym, na ile młodzi wejdą w ogóle w role rodzicielskie, na ile będą mieli okazję te role sprawować wspólnie, na ile autonomicznie, jakiego wsparcia będą w pełnieniu tych ról doświadczali. W praktyce więc to oni - zwłaszcza jeśli matką dziecka jest bardzo młoda dziewczyna - decydują o tym, jaki zakres i rodzaj doświadczeń socjalizacyjnych młodzi ludzie, w tym nastoletni ojciec dziecka, uzyskają.

Uwarunkowania ekonomiczne, a praktycznie - przy braku własnych dochodów młodych rodziców - status materialny ich rodzin, są niesłychanie ważnym czynnikiem. Nie tylko w zakresie zapewnienia młodej rodzinie, a zwłaszcza dziecku, odpowiednich warunków socjalnych, ale także jako podstawa do budowania autonomii młodych. Skrajnie trudne warunki materialne pogarszają i tak trudną sytuację nastoletnich rodziców, mnożą kłopoty, nie służą budowaniu dobrych relacji między nimi i zaangażowaniu w pełnienie roli rodziców.

Czynnikiem, który ma ważne znaczenie, jest wiek chłopaka, który został ojcem, a także wiek matki dziecka. Wpływa to nie tylko na realne możliwości sprawowania opieki nad dzieckiem, ale także na zakres akceptacji młodych w tej roli przez otoczenie, w tym członków ich rodzin. Ważny jest tu nie tylko wiek metrykalny, ale rzeczywisty poziom rozwoju poznawczego, emocjonalnego, społecznego i moralnego. Pełnienie roli ojca, roli zarezerwowanej dla osób dorosłych, może przyspieszyć proces dojrzewania do dorosłości, ale dla osób, które dzieli od tego etapu w życiu zbyt duży dystans rozwojowy, zmierzenie się z obowiązkami wynikającymi z rodzicielstwa jest zbyt dużym wyzwaniem. Nic dziwnego, że nie wszyscy mu chcą i mogą sprostać.

Opisane wyżej czynniki, które miały wpływ na obraz doświadczeń socjalizacyjnych związanych z pełnieniem roli ojca, stały się podstawą do podjęcia próby zaproponowania klasyfikacji tych doświadczeń - wyłonienia poszczególnych typów (zbyt)wczesnego ojcostwa (tab. 1). 
Tabela 1. Klasyfikacja (zbyt)młodych ojców

\begin{tabular}{|c|c|}
\hline Typ ojcostwa & Opis \\
\hline $\begin{array}{l}\text { Ojciec } \\
\text { pełnoprawny }\end{array}$ & $\begin{array}{l}\text { Może w pełni podjąć rolę ojca dzięki temu, że rodzina (rodziny) } \\
\text { zaakceptowały go w tej roli i stworzyły młodym rodzicom } \\
\text { warunki do wspólnego zajmowania się dzieckiem, wspólnego } \\
\text { zamieszkania, czasem nawet we własnym lokum; często sprzyja } \\
\text { to dużemu zaangażowaniu i odpowiedzialnemu postępowaniu; } \\
\text { czasami okazuje się, że pomimo tego chłopak nie jest w stanie } \\
\text { podołać obowiązkom; nie zawsze taką próbę wytrzymuje także } \\
\text { związek młodych rodziców }\end{array}$ \\
\hline Ojciec heroiczny & $\begin{array}{l}\text { Jest osamotniony w pełnieniu roli ojca, często pozbawiony } \\
\text { wystarczającej pomocy rodziców; bierze wszystko „na klatę”, } \\
\text { przerastające go obowiązki i sytuację, idzie do ginekologa } \\
\text { z dziewczyną, próbuje zarabiać, rezygnuje z wielu rzeczy (kumpli, } \\
\text { imprez, czasem ze szkoły...) }\end{array}$ \\
\hline (Prawie) ojciec & $\begin{array}{l}\text { Wpisuje się w warunki stworzone przez rodzinę (rodziców), } \\
\text { wspiera matkę dziecka, pomaga jej w trakcie ciąży i po urodzeniu } \\
\text { dziecka, nie musi wykazywać się heroizmem, rezygnować ze } \\
\text { wszystkiego co do tej pory było dla niego ważne; podejmuje } \\
\text { obowiązki ojca na miarę swoich sił i możliwości }\end{array}$ \\
\hline $\begin{array}{l}\text { Ojciec wizytowy, } \\
\text { dochodzący, } \\
\text { odświętny }\end{array}$ & $\begin{array}{l}\text { Jest dopuszczany do dziecka i dziewczyny jako (w miarę) } \\
\text { pożądany gość, nie musi brać na siebie odpowiedzialności, jest } \\
\text { niejako kandydatem na ojca, osobą ubiegającą się o podjęcie tej } \\
\text { roli w przyszłości }\end{array}$ \\
\hline Ojciec brat & $\begin{array}{l}\text { Rodzice (najczęściej dziewczyny) "adoptują" dziecko, w pełni } \\
\text { przejmują opiekę i odpowiedzialność za dziecko, tym samym } \\
\text { wyznaczają młodym rodzicom rolę rodzeństwa, z czasem } \\
\text { następuje często adopcja formalna }\end{array}$ \\
\hline Ojciec niegodny & $\begin{array}{l}\text { Chłopak uznany za nieodpowiedniego kandydata na ojca } \\
\text { i partnera dziewczyny (najczęściej przez rodziców dziewczyny, } \\
\text { czasami także przez nią samą) jest izolowany od kontaktów } \\
\text { z dzieckiem i jego matką; czasami próbuje walczyć o status } \\
\text { pełnoprawnego ojca, czasami jest mu to na rękę }\end{array}$ \\
\hline Ojciec uciekinier & $\begin{array}{l}\text { Chłopak ucieka od ojcostwa, wyrzeka się dziecka (i jego matki), } \\
\text { zaprzecza ojcostwu, czasem manifestuje wrogi stosunek do } \\
\text { dziewczyny, często zatraca się w imprezowaniu, próbuje } \\
\text { zapomnieć, zagłuszyć wyrzuty sumienia związane ze swoim } \\
\text { postępowaniem }\end{array}$ \\
\hline Ojciec nieświadomy & $\begin{array}{l}\text { Chłopak nie wie o tym, że ma zostać/został ojcem; czasem } \\
\text { znajomość z matką dziecka była przelotna i nie ma z nią żadnego } \\
\text { kontaktu; rzadziej zna matkę, ale nie przypuszcza, że to on jest } \\
\text { ojcem dziecka; bywa, że taka sytuacja jest stanem przejściowym } \\
\text { i po pewnym czasie chłopak uzyskuje informację o tym, że został } \\
\text { ojcem; w zależności od jego reakcji i innych uwarunkowań ojciec } \\
\text { nieświadomy staje się ojcem innego typu, najczęściej } \\
\text { uciekinierem, bądź ojcem wizytowym }\end{array}$ \\
\hline $\begin{array}{l}\text { Ojciec potencjalny, } \\
\text { "niedoszły" }\end{array}$ & $\begin{array}{l}\text { Ma za sobą doświadczenie zajścia dziewczyny w ciążę, decyzję } \\
\text { o aborcji, która (czasem) zapada poza nim, bądź z jego biernym } \\
\text { udziałem }\end{array}$ \\
\hline
\end{tabular}

Źródło: opracowanie własne. 
Jak widać, (zbyt)wczesne ojcostwo może nieść ze sobą bardzo zróżnicowaną pulę doświadczeń socjalizacyjnych. Nie są to w większości doświadczenia, które mogą być uznane za korzystne rozwojowo. Nic dziwnego - współcześnie rola rodzica jest na tyle złożona i tak zdefiniowana kulturowo, że sprawnie może być pełniona przez osoby dorosłe (wielu dorosłych też ma z tym kłopot, ale to już inna kwestia, wychodząca poza ramy tego opracowania). Nie oznacza to jednak, że każda sytuacja przedwczesnego ojcostwa niesie ze sobą tylko negatywne doświadczenia. Niektórzy chłopcy wynoszą z niej niemały kapitał socjalizacyjny. Dzieje się tak zwłaszcza wtedy, gdy są już w momencie uzyskania informacji o ciąży dziewczyny w miarę dojrzali, a rodzice chcą i potrafią zaproponować im taki rodzaj wsparcia, który pozwalając im w sposób aktywny pełnić rolę ojca, nie stawia przed nimi wyzwań ponad ich siły i możliwości. Analiza losów życiowych młodych ojców wykazuje, że dla niektórych z nich urodzenie się dziecka i opieka nad nim pozwoliły na wcześniejsze przekroczenie progu dorosłości i na rozpoczęcie budowania zrębów przyszłej rodziny.

\section{Druga odsłona socjalizacyjna - symulacja ojcostwa}

Opisane powyżej doświadczenia socjalizacyjne nastoletnich chłopców, którzy zostali ojcami, zostaną obecnie zestawione z sytuacją, w której ich rówieśnicy odgrywali jedynie rolę ojca w wyniku udziału w programie edukacyjnym. Był to program profilaktyki wczesnego rodzicielstwa „Bądź odpowiedzialny. Wychowanie do odpowiedzialności i partnerstwa w rodzinie", który w latach 2004-2005 opracował i wdrożył do praktyki oświatowej zespół pracowników Uniwersytetu Zielonogórskiego na zlecenie Ministerstwa Edukacji Narodowej.

Program był polską wersją amerykańskiego programu edukacyjnego o charakterze profilaktycznym „Baby Think It Over”, który zmierza do zapobiegania zbyt wczesnemu i nieodpowiedzialnemu podejmowaniu współżycia seksualnego przez młodzież i - co za tym idzie - ciążom nastolatek. Projekt był oparty na wykorzystaniu symulatora opieki nad niemowlęciem w postaci lalki, który prezentuje niektóre potrzeby małego dziecka. Autorzy polskiego projektu zrezygnowali $\mathrm{z}$ wielu rozwiązań programu amerykańskiego, ponieważ stwierdzono, że w sposób nadmierny opierał się na strachu. Uczestników programu straszono, między innymi, możliwością przyjścia na świat niepełnosprawnego dziecka, bardzo wysokimi kosztami opieki, wychowania i wykształcenia dziecka, bardzo dużą skalą opieki nad małym dzieckiem. Co prawda badania efektywności programu zrealizowane w Stanach Zjednoczonych (Out, Lafreniere 2001; Somers, Fahlman 2001) potwierdzają możliwość uzyskania wyników zakładanych przez jego autorów, to jest zniechęcenie do wczesnego rodzicielstwa oraz deklarowane odroczenie prokreacji, ale - według zespołu przygotowującego polską wersję programu - zachodziło realne niebezpieczeństwo, że udział w projekcie mógł działać paraliżująco na samą myśl o konieczności podjęcia się opieki i wychowania małego dziecka, wytworzyć całożyciową, negatywną postawę wobec rodzicielstwa. 
Polski projekt, w zamierzeniu jego autorów, podobnie jak pierwowzór amerykański, był profilaktyką rodzicielstwa nastolatków. Postanowiono jednak znacząco zmodyfikować cele programu, jego treści i sposób realizacji. W związku z tym odstąpiono od strategii straszenia, na rzecz strategii dostarczania wiedzy na temat potrzeb noworodka i sposobów ich poprawnego zaspakajania i doświadczeń ukazujących zarówno ogrom zadań stojących przed rodzicami małego dziecka, konieczność odpowiedzialnego stosunku do ich realizacji, jak i radości płynące z rodzicielstwa. W rezultacie chciano utrzymać, wzmocnić bądź ukształtować przekonanie o wartościach rodzicielstwa i jego niezwykłej roli w życiu człowieka. Program składał się z dwóch komponentów. Były to: zajęcia edukacyjne (w wymiarze 10 godz. dydaktycznych) oraz symulacja opieki nad niemowlęciem realizowana przez 48 godzin (od piątku do niedzieli) w domach rodzinnych uczniów. Istotą projektu było uczenie się przez działanie - modyfikacja postaw i nabywanie kompetencji poprzez opiekę nad elektronicznym symulatorem opieki nad niemowlęciem (Wąż 2008).

Program realizowany był w fazie eksperymentalnej w 24 szkołach usytuowanych w trzech województwach zachodniej Polski: zachodniopomorskim, lubuskim i dolnośląskim od września 2004 roku do stycznia 2005 roku, natomiast w roku szkolnym 2005/2006 wdrożony został w 88 szkołach w województwach: mazowieckim, podlaskim i wielkopolskim. W projekcie uczestniczyli uczniowie uczęszczający do III klasy gimnazjum lub I klasy szkoły ponadgimnazjalnej.

Jakie doświadczenia socjalizacyjne były udziałem nastoletnich chłopców, którzy wzięli udział w programie i podjęli się roli opiekunów symulatorów? Jakie czynniki i na ile różnicowały te doświadczenia? Do odpowiedzi na te pytania zostaną wykorzystane wyniki badań jakościowych towarzyszących eksperymentalnemu wdrożeniu programu. W pierwszej, eksperymentalnej fazie programu wzięło udział 636 chłopców (33,3\% ogółu). Uczestnicy programu wypełniali „Książeczki opiekuna”, w których zapisywali wrażenia z symulacji opieki nad niemowlęciem. Część z nich opracowała także dłuższe, swobodne teksty, dzienniki na ten temat. Analiza tych wypowiedzi pozwala na wyłonienie szeregu czynników, które miały wpływ na obraz doświadczeń socjalizacyjnych uczniów związanych z pełnieniem przez nich roli opiekunów symulatorów.

Ponieważ wszyscy uczniowie dobrowolnie brali udział w programie (reguła ta dotyczyła także ich rodziców) i podpisywali specjalne zobowiązanie do odpowiedzialnej „opieki” nad symulatorem, w opisywanej sytuacji czynnik presji, przymusu w ogóle nie wchodził w grę. Doświadczenia chłopców różnicował natomiast poziom zaangażowania, z jakim poszczególni uczniowie sprawowali tę opiekę. Generalnie można było zaobserwować, że uczniowie bardzo starali się, aby dobrze wywiązać się ze swojej roli. Oprócz ich wypowiedzi świadczą o tym wyniki symulacji odnotowane obiektywnie, dzięki zastosowaniu komputerowego zapisu jej przebiegu (w zdecydowanej większości przypadków uczniowie uzyskiwali od 90 do $100 \%$ trafnych reakcji na potrzeby sygnalizowane przez symulator).

Tym co w większym stopniu różnicuje poszczególne osoby, to ich motywacja. Część chłopców bardzo emocjonalnie traktowała swoje zadanie, opiekę nad 
symulatorem utożsamiała z opieką nad niemowlęciem, a samą rolę traktowała wręcz jak rodzicielstwo. Inni wykazywali dużą świadomość konwencji, odgrywali rolę ojców, ale daleko im było do utożsamiania symulatora z dzieckiem. Jeszcze inni traktowali opiekę nad symulatorem jako atrakcyjne zadanie dydaktyczne, okazję do zabawy, do ciekawego spędzania czasu, możliwość wykazania, sprawdzenia się, pochwalenia innym itp.

Czynnikiem, który w bardzo dużym stopniu różnicował doświadczenia socjalizacyjne chłopców, była postawa ich rodziców, w tym to, na ile weszli w rolę „dziadków” symulatora, na ile przestrzegali reguł eksperymentu przekazanych przez nauczyciela, na ile modyfikowali te reguły (poprzez to zubażali bądź wzbogacali zakres zadań nastoletniego „ojca”), na ile pomagali, na ile wyręczali, na ile wspierali, na ile sami byli zaangażowani, mogli i chcieli poświęcić swój czas i uwagę. W dużej mierze chodziło o to, na ile stworzyli w domu taką atmosferę, która sprzyjałaby przyjętej konwencji, przełamywała sztuczność sytuacji, sprzyjała aktywności dziecka, motywowała je do wysiłku, do wytrwania w realizacji niełatwego zadania. Ważne było także to, w jakim stopniu konwencję zaproponowaną w programie przyjęły inne osoby, zwłaszcza pozostali domownicy.

Na doświadczenia socjalizacyjne chłopców - opiekunów symulatorów - miała także wpływ reakcja otoczenia, zwłaszcza kolegów, to jak oceniali, komentowali realizację tego zadania oraz stopień narażenia ucznia na „ekspozycję" społeczną, to na ile sytuacja symulacji była ograniczona do najbliższych domowników, na ile poszerzało się grono aktorów - osób obserwujących ucznia w roli „ojca”, czy w czasie symulacji zdarzały się odwiedziny w domu ucznia dalszej rodziny, przyjaciól, sąsiadów, jak reagowali na pełnioną przez niego rolę. Czy chłopak chciał lub musiał wychodzić z symulatorem z domu, przebywać z nim w miejscach publicznych (w autobusie, parku, sklepie itp.), jaka była reakcja otoczenia na jego widok z "dzieckiem” w nosidełku.

Opisane wyżej czynniki, które miały wpływ na obraz doświadczeń socjalizacyjnych uczniów - uczestników programu, były podstawą do zaproponowania klasyfikacji tych doświadczeń, wyłonienia poszczególnych typów „ojca” - opiekuna symulatora (tab. 2).

Tabela 2. Klasyfikacja "ojców” - opiekunów symulatorów opieki nad niemowlęciem

\begin{tabular}{|c|c|}
\hline $\begin{array}{l}\text { Typ „ojca" - opiekuna } \\
\text { symulatora }\end{array}$ & Opis \\
\hline Zaangażowany & $\begin{array}{l}\text { Bardzo utożsamia się z rolą opiekuna symulatora, widzi } \\
\text { w nim dziecko, przeżywa sytuację opieki }\end{array}$ \\
\hline Odpowiedzialny & $\begin{array}{l}\text { Stara się sam realizować wszystkie zadania opiekuńcze, } \\
\text { bierze na siebie pełną odpowiedzialność, nie przyjmuje } \\
\text { innej pomocy rodziców poza dodatkowym instruktażem }\end{array}$ \\
\hline Uczeń & $\begin{array}{l}\text { Traktuje symulację opieki nad niemowlęciem jako swoiste } \\
\text { zadanie domowe, nie „kupuje” konwencji projektu, zależy } \\
\text { mu na zapisach efektów symulacji, na uzyskaniu jak } \\
\text { najlepszych/lepszych od innych wyników }\end{array}$ \\
\hline
\end{tabular}




\begin{tabular}{|c|c|}
\hline $\begin{array}{l}\text { Typ "ojca" - opiekuna } \\
\text { symulatora }\end{array}$ & Opis \\
\hline Niesamodzielny & $\begin{array}{l}\text { Bardzo liczy na rodziców, szuka u nich pomocy, wsparcia, } \\
\text { a nawet wyręczenia }\end{array}$ \\
\hline Życiowy & $\begin{array}{l}\text { W miarę angażuje się w sytuację symulacji opieki, } \\
\text { akceptuje konwencję, próbuje jednak przy tym żyć } \\
\text { dotychczasowym życiem, nie rezygnować ze spotkań } \\
\text { z przyjaciółmi, własnych przyjemności }\end{array}$ \\
\hline Hedonista & $\begin{array}{l}\text { Traktuje symulację opieki nad niemowlęciem jako zabawę, } \\
\text { przygodę, w specyficzny sposób traktuje konwencję „ojca" } \\
\text { symulatora, chętnie kontaktuje się z kolegami, aby się } \\
\text { pochwalić oryginalną „zabawką" }\end{array}$ \\
\hline
\end{tabular}

Źródło: opracowanie własne.

Autorom projektu bardzo zależało na tym, aby uczestniczyli w nim także chłopcy. Program bowiem w równym stopniu był adresowany do dziewcząt, jak i do chłopców. Chodziło o to, aby uświadomić uczniom, że za prokreację, jak i za opiekę nad dzieckiem odpowiadają zarówno kobiety, jak i mężczyźni. Autorzy programu mieli dużo obaw co do tego, jak chłopcy zareagują na propozycję udziału w programie oraz w jaki sposób będą wywiązywali się z obowiązków "opiekuna" symulatora. Obawy te łączyły się z od lat ugruntowaną w psychologii rozwojowej tezą, że nastoletni chłopcy są o wiele mniej dojrzali społecznie od swoich rówieśniczek. Można było się przy tym obawiać nie tylko infantylnych zachowań samych uczestników programu, lecz - może nawet bardziej - chłopców, którzy w nim nie uczestniczyli i mogli wyśmiewać swoich kolegów, którzy podjęli się takiego zadania. Przebieg programu udowodnił, że te obawy były bezpodstawne. Postawy uczniów wobec symulacji opieki nad niemowlęciem opisane powyżej też temu zaprzeczają. W toku eksperymentu udowodniono ponadto, że istnieje związek (korelacja) odpowiedzialnych postaw wobec prokreacji i rodzicielstwa z wcześniejszymi doświadczeniami młodzieży biorącej udział w programie (w tym chłopców) dotyczącymi podejmowania opieki nad osobami młodszymi, chorymi, potrzebującymi opieki.

Jakie doświadczenia socjalizacyjne były udziałem uczniów biorących udział w programie? Samo powierzenie chłopcom roli jedynego (pomijając zakładane wsparcie rodziców) odpowiedzialnego opiekuna symulatora niemowlęcia sprawiło, że te doświadczenia można uznać za specyficzne, zgodne z modelem „nowego ojca" czynnie uczestniczącego i zaangażowanego w opiekę nad najmłodszym dzieckiem. Pomimo starań autorów programu była to jednak sytuacja sztuczna, nawet przy przyjęciu konwencji zaproponowanej w programie przez ucznia i jego rodziców, sytuacja przypominała bardziej samotne rodzicielstwo. Pomimo tego można uznać, że pula doświadczeń socjalizacyjnych, która łączyła się z symulacją opieki nad niemowlęciem, była bardzo korzystna, sprzyjała budowaniu odpowiedzialności, cechy, która jest nie tylko niezbędna w przypadku opieki sprawowanej nad małym dzieckiem, ale stanowi istotę profilu osobowości człowieka dorosłego. 
W poszczególnych przypadkach doświadczenia uczniów były jednak zróżnicowane, co zostało uwidocznione w wyłonionych typach „ojca” - opiekuna symulatora. Można uznać, że najcenniejsze rozwojowo były u tych osób, które „kupiły” konwencję programu i uzyskały optymalne wsparcie swoich rodziców, mniej cenne u tych, którzy traktowali symulację tylko jako zadanie szkolne czy też możliwość ciekawej zabawy, oraz u tych, których rodzice nie włączyli się dostatecznie w realizację symulacji, bądź - przeciwnie - starali się wyręczać we wszystkim swoich synów.

\section{Różnice pomiędzy dwoma odsłonami socjalizacyjnymi}

Wydaje się ważne, aby w podsumowaniu podjętych tu analiz spróbować porównać doświadczenia socjalizacyjne, które uzyskali nastoletni chłopcy, pełniąc nietypowe dla siebie role - ojca i opiekuna symulatora niemowlęcia. Syntetyczny obraz tego porównania zawiera tabela 3.

Tabela 3. Różnice pomiędzy dwoma odsłonami socjalizacyjnymi

\begin{tabular}{|l|l|l|}
\hline \multicolumn{1}{|c|}{ Realne ojcostwo } & \multicolumn{1}{|c|}{ Symulacja ojcostwa } \\
\hline $\begin{array}{l}\text { Mechanizm } \\
\text { socjalizacyjny }\end{array}$ & Uczenie się przez działanie & Uczenie się przez działanie \\
\hline Naturalność & $\begin{array}{l}\text { Sytuacja naturalna, komplet } \\
\text { aktorów społecznych (matka, } \\
\text { ojciec, dziecko, dziadkowie) }\end{array}$ & $\begin{array}{l}\text { Sytuacja sztuczna, zadanie } \\
\text { wychowawcze, opieka nad } \\
\text { symulatorem, jego wygląd } \\
\text { i działanie są próbą } \\
\text { przezwyciężenia sztuczności, } \\
\text { brak kluczowych aktorów } \\
\text { społecznych - dziewczyny - } \\
\text { matki dziecka i jej rodziców }\end{array}$ \\
\hline $\begin{array}{l}\text { Ekspozycja } \\
\text { społeczna }\end{array}$ & $\begin{array}{l}\text { Bardzo duża; chłopiec jest } \\
\text { poddany ocenie nie tylko } \\
\text { członków rodziny, ale całego } \\
\text { otoczenia społecznego; w wielu } \\
\text { przypadkach ta ocena jest nader } \\
\text { krytyczna }\end{array}$ & $\begin{array}{l}\text { Umiarkowana; najczęściej } \\
\text { ograniczona do kregu najbliższej } \\
\text { rodziny, czasem tylko rodziców; } \\
\text { aprobatywne postawy wobec } \\
\text { realizowanego przez chłopca } \\
\text { zadania }\end{array}$ \\
\hline $\begin{array}{l}\text { Stopień } \\
\text { autonomii }\end{array}$ & $\begin{array}{l}\text { Sytuacja przymusu - decyduje } \\
\text { życie, a następnie często ktoś } \\
\text { inny (np. rodzice dziewczyny) }\end{array}$ & $\begin{array}{l}\text { Sytuacja wyboru - samodzielna } \\
\text { decyzja przystąpienia do } \\
\text { projektu (choć niezbędna także } \\
\text { decyzja rodziców) }\end{array}$ \\
\hline $\begin{array}{l}\text { Poziom i rodzaj } \\
\text { emocji }\end{array}$ & $\begin{array}{l}\text { Wysoki, najczęściej negatywne } \\
\text { emocje, stres }\end{array}$ & $\begin{array}{l}\text { Wysoki, najczęściej pozytywne } \\
\text { emocje, eustres }\end{array}$ \\
\hline $\begin{array}{l}\text { Wsparcie } \\
\text { dorosłych/ } \\
\text { rodziców }\end{array}$ & $\begin{array}{l}\text { W wielu sytuacjach brak } \\
\text { wsparcia dorosłych, zwłaszcza } \\
\text { rodziców własnych i/lub } \\
\text { dziewczyny }\end{array}$ & $\begin{array}{l}\text { Wsparcie własnych rodziców } \\
\text { wchodzácych w role } \\
\text { dziadków”, pośrednio także } \\
\text { nauczyciela }\end{array}$ \\
\hline lub całożyciowa & $\begin{array}{l}\text { Rola bardzo ograniczona } \\
\text { w czasie, podejmowana tylko } \\
\text { w trakcie projektu, przez kilka dni }\end{array}$ \\
\hline
\end{tabular}




\begin{tabular}{|l|l|l|}
\hline \multicolumn{1}{|c|}{ Realne ojcostwo } & \multicolumn{1}{|c|}{ Symulacja ojcostwa } \\
\hline $\begin{array}{l}\text { Możliwości } \\
\text { i stopień wejścia } \\
\text { w rolę ojca }\end{array}$ & $\begin{array}{l}\text { W wielu przypadkach brak } \\
\text { możliwości podjęcia zadań } \\
\text { (wejścia w rolę) i/lub utrudnienie } \\
\text { tego przez matkę dziecka i/lub jej } \\
\text { rodziców - izolacja, odtrącenie } \\
\text { i/lub brak chęci wejścia w rolę } \\
\text { (wyparcie się, ucieczka) }\end{array}$ & $\begin{array}{l}\text { We wszystkich przypadkach } \\
\text { podjęcie roli i pełnienie jej } \\
\text { z więszym bądź mniejszym } \\
\text { zaangażowaniem }\end{array}$ \\
\hline
\end{tabular}

Źródło: opracowanie własne.

W obu przypadkach można mówić o dużej efektywności zmiany postaw, gdyż mamy tu do czynienia z najbardziej skutecznym mechanizmem socjalizacyjnym, to jest uczeniem się przez działanie (własną aktywność) (Zimbardo, Ruch 1994, s. 559). Jednak, jak widać, pula doświadczeń charakterystyczna dla obu odsłon socjalizacyjnych jest odmienna. W pierwszym przypadku - realnego ojcostwa - o skuteczności decyduje naturalność sytuacji, duża ekspozycja społeczna, długi (całożyciowy) okres trwania, w drugim przypadku - „ojcostwa” symulatora - autonomia (dobrowolność decyzji), pozytywne emocje, wsparcie dorosłych, możliwość podjęcia roli w pełnym zakresie.

Najważniejszym atutem drugiej odsłony socjalizacyjnej jest jednak jej konstruktywny, edukacyjny charakter. Została ona zaaranżowana przecież po to, aby zbyt młodych na to chłopców i dziewczęta uchronić od konieczności podjęcia przez nich ról rodzicielskich. Ewaluacja programu, także ewaluacja odroczona (Wąż 2014), pozwala na stwierdzenie, że jest to możliwe. Okazuje się, że w tak „wrażliwym”, związanym z podejmowaniem aktywności seksualnej, obszarze możliwe jest działanie pedagogiczne, które w korzystny sposób modyfikuje pulę doświadczeń socjalizacyjnych nastolatków. Kolejny raz można też stwierdzić, że przemyślane oddziaływania wychowawcze pozwala słynną sentencję Cycerona Usus magister est Optimus („doświadczenie jest najlepszym nauczycielem”) poddać ważnej modyfikacji-doświadczenie mądrze zaprojektowane przez dorosłych jest najlepszym nauczycielem młodzieży.

\section{Literatura:}

Dane demograficzne GUS, 2014, http://demografia.stat.gov.pl/bazademografia/CustomSelectData.aspx?s $=$ uro\&y $=2013 \& \mathrm{t}=00$ [dostęp: 20.08.2014].

Izdebski Z., Wąż K., 2011, Edukacja seksualna. Potrzeba, oczekiwania społeczne, realizacja, „Edukacja. Studia. Badania. Innowacje" nr 1.

Izdebski Z., Wąż K., 2011, Obraz (przed) wczesnego rodzicielstwa [w:] Z. Izdebski, T. Niemiec., K. Wąż, (Zbyt)młodzi rodzice, Wydawnictwo TRIO, Warszawa.

Jaczewski A., 1992, Dojrzewanie-szczególny okres rozwoju [w:] Wychowawcze, etyczne i społeczne problemy zachowań seksualnych młodzieży, Z. Izdebski (red.), Wyd. TRR, Zielona Góra.

Kwiatkowska A.,1999, Siła tradycji i pokusa zmiany, czyli o stereotypach ptciowych [w:] Męskość i kobiecość w perspektywie indywidualnej i kulturowej, J. Miluska i P. Boski (red.), Wydawnictwo Instytutu Psychologii PAN, Warszawa. 
Mazur J., Małkowska-Szkutnik A. (red.), 2011, Wyniki badań HBSC 2010. Raport techniczny, Instytut Matki i Dziecka, Warszawa.

Muszyńska E., 2004, Warunki edukacji szkolnej dziewcząt i chtopców: różnice, ich przyczyny i skutki [w:] Płeć i rodzaj w edukacji, M. Chomczyńska-Rubacha (red.), WSH-E, Łódź.

Out J.W., Lafreniere K.D., 2001, Baby Think It Over: Using role-play to prevent teen pregnancy, „Adolescence" Vol. 36, No. 143.

Paprzycka E., 2010, Ambiwalencja - analiza socjalizacji kobiet w perspektywie gender, „Przegląd Socjologiczny" nr 59/3.

Sikorska M., 2009, Nowa matka, nowy ojciec, nowe dziecko. O nowym uktadzie sit w polskich rodzinach, Wyd. Akademickie i Profesjonalne, Warszawa.

Skowrońska-Zbierzchowska A., 2010, Doświadczenia małoletnich rodziców. Aspekty socjopedagogiczne, Wydawnictwo Uniwersytetu Gdańskiego, Gdańsk.

Somers C.L., Fahlman M.M., 2001, Effectiveness of the "Baby Think It Over" teen pregnancy prevention program, "Journal of School Health" Vol. 71.

Szlendak T., 2011, Socjologia rodziny. Ewolucja, historia, zróżnicowanie, Wydawnictwo Naukowe PWN, Warszawa.

Wąż K., 2014, Ewaluacja programu profilaktyki wczesnego rodzicielstwa, „Rocznik Lubuski”, t. 40, cz. 1, Uwarunkowania rozwoju zachowań ryzykownych, M. Farnicka, Z. Izdebski i K. Wąż (red.).

Wąż K. (red.), 2008, Bądź odpowiedzialny. Wychowanie do odpowiedzialności i partnerstwa w rodzinie. Opis programu edukacyjnego i jego realizacji, Wyd. UZ, Zielona Góra.

Wołosik A., Edukacja do równości, czy trening uległości ? Internetowa szkoła równości i demokracji, http://www.wstronedziewczat.org.pl/downloads/ania_genderfair.pdfS.10 [dostęp: 09.04.2011].

Woynarowska B., Szymańska M.M., Mazur J., 1999, Wiedza i przekonania o HIV/AIDS. Zachowania seksualne. Raport z badań wykonanych w 1998 r., Katedra Biomedycznych Podstaw Rozwoju i Wychowania, Wydział Pedagogiczny UW, Warszawa.

Zimbardo Ph.G., Ruch F.L., 1994, Psychologia i życie, Wydawnictwo Naukowe PWN, Warszawa.

\section{Summary}

Teenage boys as fathers: two perspectives

This article is an empirical exploration of the early fatherhood as a real life experience and an educational experiment. The author reveals the regulative role that 'simulated' fatherhood plays in the construction of concepts of man as a father.

\section{Keywords}

teenager, fatherhood, socialization, early fatherhood, identity

\section{Słowa kluczowe}

nastolatek, ojcostwo, socjalizacja, wczesne ojcostwo, tożsamość 